\title{
Fluktuasi Populasi dan Keragaman Musuh Alami Hama Wereng Batang Coklat (Nilaparvata lugens Stal.) pada Lahan Padi Sawah di Wilayah Universitas Wiralodra, Kabupaten Indramayu, Jawa Barat
}

\author{
Martua Suhunan Sianipar \\ Departemen Hama dan Penyakit Tumbuhan, Fakultas Pertanian, Universitas Padjadjaran \\ Kampus Jatinangor, Jatinangor 45363 \\ *Alamat korespondensi: suhunan@unpad.ac.id
}

\begin{abstract}
Population fluctuation and natural enemy diversity of brown planthopper (Nilaparvata lugens Stal.) in the rice lowlands of Wiralodra University Area, Indramayu Regency, West Java
\end{abstract}

Brown Planthopper/BPH (Nilaparvata lugens Stal.) is a main pest of paddy. The purpose of this research was to study the population fluctuation and natural enemy diversity of BPH in rice plants. The research was carried out with a survey method conducted on three experimental lands located in the lowlands of Wiralodra University, Singaraja Village, Indramayu District, Indramayu Regency, West Java and in the greenhouse of the Department of Plant Pests and Diseases, Faculty of Agriculture, Universitas Padjadjaran from June to August 2015. The samples were collected by systematically diagonal sampling method using yellow stiky trap and manually or visual counting. The result showed that the BPH population fluctuations were below BPH economic threshold the results of correlation analysis showed that temperature, humidity and rainfall did not have a significant influence on the abundance of the BPH population. This is indicated by the results of regression analysis of temperature $(\mathrm{Y}=-49.9+1.71 \mathrm{X} 1 ; \mathrm{R} 2=0.055$; $\mathrm{P} / \mathrm{Sign}=0.484)$, humidity $(\mathrm{Y}=-$ $41.829+0.598 \mathrm{X} 2 ; \mathrm{R} 2=0.457 ; \mathrm{P} / \mathrm{Sign}=0.016)$, and rainfall $(\mathrm{Y}=2.845+0.512 \mathrm{X} 3 ; \mathrm{R} 2=0.217 ; \mathrm{P} / \mathrm{Sign}$ $=0.127)$, respectively. The relationship between temperature $/ \mathrm{T}$, humidity $/ \mathrm{RH}$ and rainfall/ $\mathrm{CH}$ on $\mathrm{WBC}(\mathrm{Y}=-94.2+3.00 \mathrm{~T}+0.002 \mathrm{RH}+0.804 \mathrm{CH} ; \mathrm{R} 2=0.581 ; \mathrm{P} /$ ign $=0.062)$ had a significance level $>0.05$. The natural enemy insect diversity index was in the medium category (1.63).

Keywords: BPH, Abiotic factor, Natural Enemy, Lowland rice

\begin{abstract}
ABSTRAK
Wereng Batang Cokat/WBC (Nilaparvata lugens Stal.) merupakan hama utama tanaman padi. Penelitian ini bertujuan untuk mempelajari fluktuasi populasi serta keragaman musuh alami WBC pada tanaman padi. Penelitian ini dilakukan dengan metode survei yang dilakukan pada tiga lahan percobaan yang bertempat dataran rendah di wilayah Universitas Wiralodra, Desa Singaraja, Kecamatan Indramayu, Kabupaten Indramayu, Jawa Barat dan di rumah kaca Departemen Hama dan Penyakit Tumbuhan Fakultas Pertanian Universitas Padjadjaran pada bulan Juni sampai Agustus 2015. Metode pengambilan sampel dilakukan secara diagonal menggunakan perangkap kuning berperekat (yellow stiky trap) serta secara manual (visual counting). Hasil penelitian menunjukkan fluktuasi populasi WBC berada di bawah ambang ekonomi WBC dan hasil analisa korelasi menunjukkan suhu, kelembaban dan curah hujan tidak memberikan pengaruh yang signifikan terhadap kelimpahan populasi WBC. Hal ini ditunjukkan dengan hasil analisis regresi masing-masing pada suhu $\left(\mathrm{Y}=-49.9+1.71 \mathrm{X}_{1} ; \mathrm{R}^{2}=0,055 ; \mathrm{P} / \mathrm{Sign}=0,484\right)$, kelembaban $\left(\mathrm{Y}=-41.829+0.598 \mathrm{X}_{2} ; \mathrm{R}^{2}=\right.$ $0,457$; P/Sign $=0,016)$ dan curah hujan $\left(\mathrm{Y}=2.845+0.512 \mathrm{X}_{3} ; \mathrm{R}^{2}=0,217 ; \mathrm{P} / \mathrm{Sign}=0,127\right)$. Adapun hubungan antara Suhu/T, Kelembaban/RH dan Curah Hujan/CH terhadap WBC (Y $=-94.2+3.00 \mathrm{~T}$
\end{abstract}


$+0.002 \mathrm{RH}+0.804 \mathrm{CH} ; \mathrm{R} 2=0.581 ; \mathrm{P} / \mathrm{Sign}=0.062)$ memiliki tingkat signifikansi $>0,05$. Indeks keragaman serangga musuh alami WBC termasuk kategori sedang $(1,63)$.

Kata Kunci: WBC, Fakor Abiotik, Musuh alami, Lahan sawah

\section{PENDAHULUAN}

Serangan organisme pengganggu tumbuhan seperti hama dan penyakit merupakan salah satu kendala biologis dalam produksi dan ketahanan pangan di Indonesia. Perubahan lingkungan akan berpengaruh positif atau negatif terhadap perkembangan organisme pengganggu tanaman baik hama, patogen maupun gulma. Wereng Batang Coklat (WBC), Nilaparvata lugens Stal. pertama kali dilaporkan telah menjadi hama tanaman padi di Indonesia tahun 1854 oleh Stal dan sejak 1970 telah merupakan hama utama tanaman padi di Indonesia (Untung, 1995). Hama ini sampai sekarang selalu menjadi kendala pada peningkatan produksi padi di Indonesia. Menurut Sumiati (2011) hama ini telah menjadi hama global (the very important global pest). Serangan hama WBC meluas hampir di seluruh sentra produksi padi dengan serangan yang berbeda mulai dari serangan ringan sampai puso kering seperti terbakar atau hopperburn. Bahayanya, ledakan WBC tidak hanya terjadi pada lahan padi sawah, tetapi juga pada lahan padi gogo.

Kelimpahan populasi serangga WBC disuatu habitat atau ekosistem pada dasarnya dibentuk oleh adanya keanekaragaman dan kelimpahan sumber pakan dan sumber lainnya seperti musuh alami. Musuh alami mengatur kelimpahan populasi serangga herbivor dihabitatnya. Pengaturan oleh musuh alami yang bekerja tergantung kepadatan pada populasi serangga herbivor mengakibatkan populasi serangga akan berfluktuasi (Soesilohadi, 2002).

Disamping itu WBC secara tidak langsung menjadi vector virus, sehingga pada saat menusuk dapat menularkan penyakit Virus Kerdil Rumput (rice grassy stunt virus $=\mathrm{VKR}$ ) tipe 1 dan tipe 2 dan Virus Kerdil Hampa (rice ragged stunt virus $=\mathrm{VKH}$ ) (Cabauatan et al., 2009; Baehaki, 2011). Pujiharti dkk. (2008) melaporkan ambang ekonomi WBC jika terdapat 15 ekor/rumpun padi. Jika jumlah WBC mencapai 15 ekor/rumpun pada saat tanaman padi berumur satu bulan, maka tanaman padi dalam waktu 10 hari akan puso (BBPT Padi, 2012). Gohan (2015) menyatakan ambang ekonomi WBC apabila ditemukan rata rata 10 ekor/rumpun pada tanaman padi yang berumur kurang dari 40 Hari Setelah Tanam (HST) atau rata rata 20 ekor/ rumpun pada tanaman padi yang berusia lebih dari $40 \mathrm{HST}$.

Keberadaan WBC pada lahan sawah dipengaruhi oleh faktor biotik dan abiotik (Dianawati \& Sujitno, 2015). Faktor biotik yang memengaruhi keberadaan WBC di lahan diantaranya yaitu varietas tanaman padi serta keberadaan musuh alami. Penggunaan varietas padi rentan merupakan salah satu faktor yang menyebabkan kemunculan WBC di lahan sawah (Rahmini dkk., 2012). Menurut Gunawan dkk. (2015), keberadaan musuh alami dapat memengaruhi populasi WBC yang berada pada lahan sawah. Faktor abiotik yang memengaruhi keberadaan WBC di lahan antara lain suhu, kelembaban dan curah hujan (Nurbaeti dkk., 2010).

Kartohardjono (2011) menyatakan bahwa pengendalian serangga hama dengan menggunakan musuh alami merupakan tindakan untuk mengurangi tingkat pencemaran yang disebabkan oleh pestisida sintetik, pengendalian hama akan lebih efisien, berkelanjutan, tidak megganggu dan merusak keragaman hayati serta kompetibel. Pengendalian hayati dapat dilakukan dengan menggunakan predator, parasitoid dan patogen. Berdasarkan latar belakang yang telah dikemukakan di atas penelitian ini bertujuan mempelajari fluktuasi populasi serangga hama WBC, bagaimana pengaruh suhu, kelembapan dan curah hujan terhadap fluktuasi populasi serangga hama WBC, keragaman musuh alami (predator dan parasitoid) serangga hama WBC.

\section{BAHAN DAN METODE}

Percobaan dilaksanakan di lahan sawah dataran rendah pada musim kemarau di wilayah Universitas Wiralodra, Desa Singaraja, Kecamatan Indramayu, Jawa Barat pada bulan Juni 2015 sampai Agustus 2015 pada ketinggian 18 mdpl. Penelitian dilakukan dengan metode observasi ekologi. Percobaan diawali dengan menyemai benih padi varietas Ciherang. Setelah padi berumur 4 minggu Setelah Semai (MSS) benih padi dipindahkan ke lahan sawah percobaan. Pengambilan sampel pada 
lahan dilakukan secara diagonal sistematis. Pengambilan sampel WBC dan musuh alami predator serta parasitoid WBC dilakukan dengan metode nisbi dengan menggunakan perangkap kuning berperekat (yellow sticky trap/YST), dan secara manual dengan menghitung langsung (visual counting) dari lokasi sampel dengan menggunakan hand counter, serta yellow pan trap/YPT yang diutamakan untuk menangkap musuh alami hama WBC.

Percobaan dilaksanakan pada 3 lahan yang berbeda dengan luas masing masing lahan 15 x 20 $\mathrm{m}^{2}$. Pengamatan dan pengambilan sampel dilaksanakan sebanyak 12 kali dengan selang waktu pengamatan 1 minggu sekali sejak tanaman berumur lima MST pada padi fase vegetatif dan generatif yang dibudidayakan secara konvensional. Pengamatan kepadatan populasi WBC dilakukan berdasarkan penetapan sampel secara diagonal yang dilakukan terhadap 10 rumpun padi/titik sampel (10-15\% dari banyaknya rumpun padi/titik sampel = 10 rumpun). Satu perangkap YPT diletakkan di bagian tengah lokasi penempatan sampel diagonal setinggi 0.7 mdpl.

Penelitian dilakukan dengan cara menghitung jumlah individu WBC dan spesiesspesies predator dan parasitoid WBC secara manual atau langsung dengan menggunakan hand counter maupun yang tertangkap di setiap perangkap kuning berperekat (yellow sticky trap). Bila secara visual ada keraguan penetapan spesies serangga khususnya predator dan parasitoid, serangga hama WBC dan musuh alami (predator dan parasitoid) WBC yang didapatkan diidentifikasi dengan kunci identifikasi Pengenalan Pelajaran Serangga (Borror dkk., 1996), Taxonomy of Rice Insect Pest and their Arthropod Parasites and Predator (Barrion \& Litsinger, 1994). Identifikasi juga dilaksanakan dengan mencocokkannya dengan gambar dan keterangan dari buku The Pest of Crops in Indonesia (Kalshoven, 1981).

Data jumlah WBC yang telah diperoleh dianalisis dengan menggunakan Software SPSS 17. Hubungan antara lingkungan abiotik variabel bebas (independent variable) yaitu suhu, kelembaban dan curah hujan terhadap variabel tergantung (dependent variable) yaitu populasi WBC yang dianalisis dengan model regresi linier sederhana (Gesperz, 1991). Untuk mengetahui hubungan antara variabel bebas secara bersamaan terhadap variable tergantung dilakukan dengan Persamaan Regresi Linier Berganda dan Data diolah menggunakan software Minitab 16. Data keragaman musuh alami dianalisis dengan menggunakan perhitungan indeks keragaman menurut Shanon Weiner (Krebs, 1989) sebagai berikut:

$\mathrm{H}^{\prime}=-p_{i} \ln p_{i}$

$\mathrm{H}^{\prime}=$ Indeks keragaman spesies

$\mathrm{p}^{\mathrm{i}}=$ Perbandingan jumlah individu suatu jenis $\left(\mathrm{n}_{\mathrm{i}}\right)$ dengan keseluruhan jenis spesies yang terkoleksi (N).

Kriteria indeks keragaman $(\mathrm{H})$ serangga musuh alami (Michael, 1995) adalah:

Keragaman jenis rendah bila $\mathrm{H}<1,5$

Keragaman jenis sedang bila 1,5 $\leq \mathrm{H} \leq 3,5$

Keragaman jenis tinggi bila $\mathrm{H}>3,5$

\section{HASIL DAN PEMBAHASAN}

Hasil pengamatan populasi WBC pada tanaman padi varietas Ciherang serta pengukuran suhu, kelembaban dan curah hujan disajikan pada Tabel 1. Data pada Tabel 1 menunjukkan pada pengamatan ke-2 MST baru ditemukan WBC sebanyak 3 individu/10 rumpun dan terus meningkat hingga pengamatan ke-6 MST sebanyak 12 individu/10 rumpun. Kemudian mulai minggu ke-7 MST hingga pengamatan minggu ke-12 MST terjadi penurunan populasi WBC dengan jumlah berturut-turut $10,9,6,5,3$, dan 1 individu/10 rumpun. Hasil pengamatan suhu berkisar antara $30,7-32,2^{\circ} \mathrm{C}$, kelembaban antara $71,5-81,0 \%$ serta curah hujan antara 0-9 mm/MST. Hubungan antara faktor abiotik suhu, kelembaban, dan curah hujan terhadap populasi WBC disajikan pada Tabel 2.

Hubungan antara suhu terhadap populasi WBC adalah lemah $(r=0,235 ;$ Sign $=0,484)$. Disebutkan bahwa: $r<0,35$ hubungan lemah; $r=$ 0,36-0,67 hubungan sedang; $r>0,68-1$ hubungan kuat (Taylor, 1990). Persamaan regresi linier sederhana tersebut tidak mewakili hubungan antar suhu dengan populasi WBC karena peluang Sig > 0,05 (Sig. 0,484). Hubungan antara kelembaban terhadap populasi WBC adalah sedang $(r=0,676)$. Persamaan regresi linier sederhana tersebut mewakili hubungan antar kelembaban dengan populasi WBC karena peluang Sig < 0,05 (Sig. 0.016). Hubungan antara curah hujan terhadap populasi WBC adalah sedang $(r=0,465)$. Persamaan regresi linier sederhana tersebut tidak mewakili hubungan antar curah hujan dengan populasi WBC karena peluang Sig > 0,05 (Sig. 0,127). Suhu, kelembaban dan curah hujan bersama-sama memengaruhi populasi WBC sebesar 58,1\%. Dengan demikian, 
41,9\% dipengaruhi oleh faktor lain selain ketiga faktor tersebut. Persamaan regresi linier berganda tersebut tidak mewakili hubungan antar ketiga faktor tersebut dengan populasi WBC karena peluang Sig > 0,05 (Sig. 0,062).

Hasil penelitian pada pengamatan 2 MST ditemukan WBC sebanyak 3 individu/10 rumpun. Hal ini diduga disebabkan terjadinya penanaman padi dan panen padi yang tidak serentak di sekitar lahan penelitian. Penanaman padi oleh petani sekitar juga lebih awal dari penanaman padi penelitian sehingga selalu tersedia pakan dilahan persawahan. Hal ini sesuai dengan hasil penelitian
Baehaki (2011) menyatakan jika pertanaman dilakukan tidak serempak saat pertanaman tetangganya terserang WBC, maka daerah demikian akan terjadi sumber hama yang tiada hentinya. Hal ini terjadi karena adanya ketersediaan pakan di areal pertanaman (Makarim \& Suhartatik, 2009). Serangga mulai tertarik pada tanaman padi yang telah berumur 10-20 hari setelah tanam (Kisimoto, 1977 dalam Baehaki \& Widiarta, 2008). Kemudian pada pengamatan yang dilakukan tiap minggunya pada pengamatan ke 6 MST yang merupakan padi pada fase vegetatif merupakan puncak kehadiran hama WBC.

Tabel 1. Data populasi WBC, suhu udara, kelembaban udara dan curah hujan.

\begin{tabular}{ccccc}
\hline MST (minggu) & Populasi WBC (10 rumpun) & Suhu $\left({ }^{\circ} \mathrm{C}\right)$ & Kelembaban $(\%)$ & Curah hujan (mm/MST) \\
\hline 1 & 0 & 30,7 & 75,2 & 0 \\
2 & 3 & 31,3 & 73,2 & 2 \\
3 & 7 & 31,6 & 74,7 & 0 \\
4 & 7 & 32,2 & 75,5 & 0 \\
5 & 9 & 30,9 & 80,2 & 9 \\
6 & 12 & 31,9 & 80,7 & 2 \\
7 & 10 & 31,7 & 77,2 & 5 \\
8 & 9 & 31,9 & 81,0 & 6 \\
9 & 6 & 31,2 & 78,0 & 0 \\
10 & 5 & 32,2 & 75,7 & 0 \\
11 & 3 & 31,5 & 73,7 & 0 \\
12 & 1 & 31,5 & 71,5 & \\
\hline
\end{tabular}

Tabel 2. Hubungan antara faktor abiotik suhu, kelembaban, curah hujan terhadap populasi WBC.

\begin{tabular}{|c|c|c|c|c|}
\hline Faktor Iklim & $\begin{array}{l}\text { Koefisien } \\
\text { Korelasi/r }\end{array}$ & $\begin{array}{c}\text { Koefisien } \\
\text { Detreminasi/ } \mathrm{R}^{2}\end{array}$ & Persamaan regresi & Sig \\
\hline Suhu/T $\left(\mathrm{X}_{1}\right)$ & 0,235 & 0,055 & $Y=-49,9+1,71 \mathrm{X}_{1}$ & 0,484 \\
\hline Kelembapan/RH ( $\left.\mathrm{X}_{2}\right)$ & 0,676 & 0,457 & $Y=-41,829+0,598 X_{2}$ & 0,016 \\
\hline 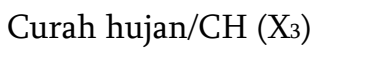 & 0,465 & 0,217 & $Y=2,845+0,512 X_{3}$ & 0,127 \\
\hline $\mathrm{T} /\left(\mathrm{X}_{1}\right), \mathrm{RH}(\mathrm{X} 2), \mathrm{CH}(\mathrm{X} 3)$ & 0,762 & 0,581 & $\begin{array}{l}\mathrm{Y}=-94,2+3,00 \mathrm{~T}+0,002 \mathrm{RH} \\
+0,804 \mathrm{CH}\end{array}$ & 0,062 \\
\hline
\end{tabular}

Keterangan: $\mathrm{X}_{1}=\mathrm{Suhu} / \mathrm{T}, \mathrm{X}_{2}=$ Kelembaban/ RH, $\mathrm{X}_{3}=$ Curah Hujan/ CH. Persamaan regresi berpengaruh nyata jika angka Sig $<0.05$.

Pada fase vegetatif sebelum pembentukan bulir, populasi WBC terus bertambah dimana dalam fase ini tanaman padi diduga cenderung menyerap lebih banyak unsur nitrogen untuk pembentukan protein yang mana dapat juga menjadi sumber nutrisi bagi WBC (Campbell dkk., 2008; Rashid dkk., 2016). Dilaporkan bahwa kandungan nitrogen yang tinggi pada tanaman padi dapat memicu peningkatan populasi WBC (Kadja, 2015). Selanjutnya pada pengamatan yang dilakukan tiap minggunya pada pengamatan ke 7 MST mulai terjadi penurunan jumlah WBC pada tanaman padi hingga fase generatif akhir yaitu pada pengamatan ke 12 MST. Kurangnya ketersediaan pupuk $\mathrm{N}$ diduga menyebabkan kurangnya ketersediaan unsur $\mathrm{N}$ pada tanaman padi yang merupakan kebutuhan hidup WBC. Pada fase generatif tanaman lebih banyak membutuhkan dan menyerap unsur $\mathrm{P}$ dan $\mathrm{K}$ untuk 
pembentukan bulir padi. Pada fase generatif tanaman padi lebih sedikit menyerap unsur $\mathrm{N}$ akibatnya saat mendekati fase generatif imago WBC membentuk sayap Makroptera untuk mencari inang lain yang lebih sesuai. Biasanya WBC makroptera bermigrasi saat tanaman baru ditanam (Baehaki \& Widiarta, 2008).

Dilaporkan bahwa suhu antara $25-30^{\circ} \mathrm{C}$ merupakan suhu optimal untuk perkembangan telur dan nimpha WBC dan pada kisaran suhu tersebut serangan WBC dapat menimbulkan terjadinya hopperburn pada tanaman padi (IRRI, 1979). Sementara itu, kelembaban relatif optimal bagi pertumbuhan populasi WBC adalah 50-60\%. Populasi WBC akan cepat meningkat pada kelembaban tinggi (70-80\%), intensitas cahaya matahari rendah, lahan basah, pemupukan $\mathrm{N}$ tinggi, tanaman rimbun, angin rendah dan suhu siang hari optimum $\left(28-30^{\circ} \mathrm{C}\right)$ (Nurbaeti dkk., 2010). Curah hujan di dataran rendah $0.0-9.0 \mathrm{~mm} / \mathrm{minggu}$ pada musim kemarau diduga menyebabkan rendahnya populasi WBC. Terbukti hasil analisis regresi populasi WBC dengan suhu, kelembaban dan curah hujan menunjukkan korelasi antara fluktuasi populasi WBC dengan faktor abiotik yang diamati tidak berpengaruh siginifikan terhadap peningkatan populasi WBC karena nilai signifikansinya lebih dari 0,05 .
Secara umum, hasil penelitian menunjukkan bahwa populasi WBC di lokasi penelitian masih jauh di bawah ambang ekonomi. Meskipun daerah Indramayu dikenal sebagai daerah endemik WBC, populasi WBC yang rendah ini dapat dipengaruhi oleh beberapa faktor. Lokasi yang bukan merupakan daerah khusus ledakan WBC, penanaman varietas padi yang berganti-ganti, pembersihan lahan sawah dari gulma, serta penggunaan pestisida secara teratur dapat memengaruhi populasi WBC.

Beberapa spesies musuh alami WBC pada tanaman padi Varietas Ciherang berhasil diidentifikasi dengan menggunakan kunci identifikasi (Tabel 3). Spesies-spesies predator yang berpotensi dapat menurunkan kepadatan populasi WBC yaitu Tetragnatha maxillosa (Laba-laba rahang), Micraspis inops (Kumbang kubah), Coccinella repanda (kumbang coccinella), Paederus fuscipes (tomcat), Microvelia douglasi (Kepinding air), dan Lycosa pseudoanulata (Laba-laba srigala). Hasil penelitian yang dilakukan spesies predator Lycosa pseudoanulata (Laba-laba srigala) paling banyak populasinya mencapai 22 ekor/10 rumpun dan spesies Microvelia douglasi merupakan serangga predator yang paling sedikit populasinya hanya 2 ekor/10 rumpun dengan Indeks Keragaman sedang 1,63 .

Tabel 3. Spesies-spesies predator serangga hama WBC.

\begin{tabular}{llllc}
\hline \multicolumn{1}{c}{ Spesies } & \multicolumn{1}{c}{ Nama umum } & \multicolumn{1}{c}{ Kelompok } & \multicolumn{1}{c}{$\begin{array}{c}\text { Stadia WBC } \\
\text { sasaran }\end{array}$} & $\begin{array}{c}\text { Jumlah/10 } \\
\text { rumpun }\end{array}$ \\
\hline Tetragnatha maxillosa & Laba-laba rahang & Predator & Nimfa & 8 \\
Micraspis inops & Kumbang kubah & Predator & Nimfa & 11 \\
Coccinella repanda & Kumbang Coccinella & Predator & Nimfa & 13 \\
Paederus fuscipes & Kumbang Tomcat & Predator & Nimfa \& Imago & 9 \\
Microvelia douglasi & Kepinding air & Predator & Nimfa & 2 \\
Lycosa pseudoanulata & Laba-laba srigala & Predator & Nimfa & 22 \\
\hline
\end{tabular}

Keterangan: Nilai H' = 1,63 Indek Keragaman Sedang

Hasil uji indek keragaman $(\mathrm{H})$ musuh alami spesies predator WBC di atas menunjukkan kualitas ekosistem lahan sawah. Hasil uji keragaman musuh alami WBC berdasarkan perhitungan Indeks Keragaman (H) menurut Shanon Weiner (Krebs, 1989) menunjukkan bahwa musuh alami WBC di lahan percobaan adalah keragaman jenis sedang yaitu $\mathrm{H} 1,5 \leq \mathrm{H} \leq 3,5$. Tiga jenis keragaman serangga yaitu bila $\mathrm{H}^{\mathrm{i}} \leq 1$ berarti keanekaragaman serangga rendah dimana keberadaan serangga dan musuh alami di lapangan tidak berimbang yang dapat membuat kerusakan tanaman; bila $\mathrm{H}^{\mathrm{i}}$ antara 1-3 berarti keanekaragaman serangga sedang yaitu mengarah ke baik dimana keberadaan hama dan musuh alami di lapangan hampir seimbang; dan $\mathrm{H}^{\mathrm{i}} \geq$ 3 berarti keanekaragaman serangga tinggi dimana keadaan ekosistem yang ada di lapangan adalah seimbang antara hama dan musuh alaminya sehingga tidak perlu dilakukan perlakuan pengendalian serangga (Michael, 1995).

Kemampuan musuh alami spesies predator maupun parasitoid untuk tetap dapat hidup meskipun dengan jumlah populasi yang berbedabeda diduga disamping memangsa WBC, predator di 
atas juga mempunyai makanan inang lain. Pendugaan ini sesuai hasil penelitian Santosa \& Sulistyo (2007) yang melaporkan bahwa musuh alami serangga predator maupun parasitoid selalu terdapat pada lahan meskipun tanaman padi sudah tidak ada karena predator memangsa inang dan stadia serangga yang berbeda beda. Menurut Untung (1995) perubahan spesies dan populasi serangga hama dan musuh alami di lahan padi sawah pada setiap waktu pengamatan dapat terjadi karena setiap populasi pada ekosistem tidak pernah sama dari waktu ke waktu, namun terjadi kenaikan dan penurunan.

\section{SIMPULAN}

Berdasarkan hasil penelitian dapat disimpulkan bahwa populasi WBC di lahan sawah musim kemarau dataran rendah Desa Singaraja, Kecamatan Indramayu, Kabupaten Indramayu masih dibawah ambang ekonomi WBC. Hubungan antara iklim (suhu, kelembaban dan curah hujan) terhadap populasi WBC hasil uji statistik regresi linier sederhana maupun regresi linier berganda berada pada level lemah Hasil uji regresi linier sederhana maupun regresi linier berganda tersebut tidak mewakili hubungan antara ketiga faktor dengan populasi WBC karena peluang sig > 0.05. Musuh alami Wereng Batang Coklat (WBC) yang ditemukan hanya spesies predator Indeks keragaman musuh alami WBC berada pada Indeks Keragaman level sedang. Keberadaan lahan percobaan dengan indeks keragaman musuh alami sedang mulai menunjukkan ekosistem lahan dalam keadaan mulai tidak seimbang.

\section{UCAPAN TERIMA KASIH}

Penulis mengucapkan terima kasih kepada Direktorat pendidikan Tinggi, Kementerian Riset, Teknologi dan Pendidikan Tinggi, serta Dekan Fakultas Pertanian Universitas Wiralodra Kabupaten Indramayu.

\section{DAFTAR PUSTAKA}

Baehaki, SE. 2011. Strategi fundamental pengendalian hama wereng batang coklat dalam pengamanan. Pengembangan Inovasi Pertanian. 4(1): 15-16.

Baehaki, SE, dan Widiarta. 2008. Hama Wereng dan Cara Pengendaliannya pada Tanaman Padi.
Sukamandi, Subang.

Basri, AB. 2012. Mengenal wereng batang coklat. Seri Inovasi Pembangunan-Serambi Pertanian. 6(2): 1-2.

Barrion, AT, and AJ Litsinger. 1994. Taxonomy of rice insect pests and their arthropod parasites and predators. In Biology and Management of Rice Insects (EA Heinrichs, Ed.). Pp. 13-359. Wiley Eastern LimitedNew Age International Limited, New Delhi.

BBPT Padi. 2012. VUB Padi Sawah: Jawa Barat sebagai Pemasok Beras Nasional. Tersedia online pada www.litbang.deptan.go.id/berita/one/1188. (diakses 20 Maret 2018)

Borror, JD, DM De Long, and CA Triplehorn. 1989. An Introduction to The Study of Insects. Saunders College Publishing, Philadelphia.

Cabauatan, PQ, RC Cabunagan, and IR. Choi. 2009. Viruses transmitted by the brown planthopper (Nilaparvata lugens Stal.). In Planthoppers: New Threats to The Sustainability of Intensive Rice Production Systems in Asia (KL Heong, B Hardy, Eds.). Pp. 357-368. International Rice Research Institute, Los Banos, Philippines.

Campbell, N. 2008. Biologi. Edisi Ke-8. Erlangga, Jakarta.

Dianawati, M, dan E Sujitno. 2015. Kajian berbagai varietas unggul terhadap serangan wereng batang cokelat dan produksi padi di lahan sawah kabupaten Garut, Jawa Barat. Prosiding Seminar Nasional Masyarakat Biodiveristy Indonesia. 1(14): 868-873.

Gohan, OM. 2015. Pengendalian Hama Terpadu Wereng Batang Coklat. Balai Pengkajian Teknologi Pertanian Lampung. Badan Penelitian dan Pengembangan Pertanian Kementerian Pertanian.

Gunawan, CSE, G Mudjiono, dan LP Astuti. 2015. Kelimpahan populasi wereng batang coklat Nilaparvata lugens Stal. (Homoptera: Delphacidae) dan laba-laba pada budidaya tanaman padi dengan penerapan pengendalian hama terpadu dan konvensional. Jurnal HPT. 3(1): 117-122.

IRRI. 1979. Up Line Rice. International Rice Research Institution. Los Banos, Philippines.

Kadja, DH. 2015. Pengaruh jenis pupuk dan tinggi genangan air terhadap perkembangan populasi wereng batang padi coklat pada 
tanaman padi. Jurnal Ilmu Pertanian. 18(1): 18-23.

Kalshoven, LGE. 1981. The Pest of Crops in Indonesia. PT. Ichtiar Baru Van Hoeve, Jakarta.

Kartohardjono, A. 2011. Penggunaan musuh alami sebagai komponen pengendalian hama padi berbasis ekologi. Jurnal Pengembangan Inovasi Pertanian. 4(1): 29-46.

Krebs, CJ. 1989. Ecology: The Experimental Analysis of Distribution and Abudance. $3^{\text {rd }}$ Ed. Harper and Row Publishing, New York.

Makarim, AK, dan E Suhartatik. 2009. Morfologi dan Fisiologi Tanaman Padi. Balai Besar Penelitian Tanaman Padi. Sukamandi, Subang.

Michael, P. 1995. Methoda Ekologi untuk Penyelidikan lapangan dan Laboratorium. (YR Koestoer, Ed.). UI Press, Jakarta.

Nurbaeti, B, IGPA Diratmaja dan S Putra. 2010. Hama Wereng Coklat (Nilaparvata lugens Stal.) dan Pengendaliannya. Balai Pengkajian Teknologi Pertanian Jawa Barat.

Pujiharti, Y, J Barus, dan B Wijayanto. 2008. Teknologi Budidaya Padi. Balai Besar Pengkajian dan Pengembangan Teknologi Pertanian. Lampung.
Rahmini. 2012. Respon biologi wereng batang coklat terhadap biokimia tanaman padi. Penelitian Pertanian Tanaman Pangan. 2(31): 117-123.

Rashid, M. 2016. Impact of nitrogen, phosporus and potassium on brown planthopper and tollerancde of its host rice plant. Rice Science. 23(3): 119-131.

Santosa, SJ, dan J Sulistyo. 2007. Peranan musuh alami hama utama padi pada ekosistem sawah. Jurnal Inovasi Pertanian. 6(1): 1-10.

Soesilohadi, RCH. 2002. Dinamika Populasi Lalat Buah, Bactrocera carambolae Drew and Handcock (Diptera; Tephritidae). Disertasi. Institut Teknologi Bandung. Bandung. [Tidak dipublikasikan]

Sumiati, A. 2011. No Pengendalian Hama Batang Wereng Cokelat pada Tanaman Padi. Balai Pengkajian Teknologi Pertanian Jambi. Balai Besar Pengkajian dan Pengembangan Teknologi Pertanian Kementerian Pertanian.

Taylor, R. 1990. Interpretation of the correlation coefficient: A basic review. Journal of Diagnostic Medical Sonography. 6(1): 35-39.

Untung, K. 1995. Pengantar Pengelolaan Hama. Gadjah Mada University Press, Yogyakarta. 